Ana Dili Eğitimi Dergisi
Journal of Mother Tongue Education
www.anadiliegitimi.com
Geliş/Received: 28.08 .2020 Kabul/Accepted:21.10.2020
Araştırma Makalesi / Research Paper

\title{
Dijital Öykülerin Türkçe Dil Becerilerinin Gelişimine Etkisi: Bir Meta Analiz Çalışması
}

\author{
Perihan Gülce ÖZKAYA*
}

\begin{abstract}
Öz
Bu çalışmanın amacı, dijital öykülerin Türkiye'de farklı öğrenim düzeylerindeki öğrencilerin Türkçe dil becerilerinin gelişimine etkisinin belirlenmesidir. Bu amaç doğrultusunda dijital öykülerin Türkçe dil becerilerinin gelişimine etkisini inceleyen araştırmaların meta analizi yapılmışır. Meta analiz çalışmasına 11 araştırma dâhil edilmiştir. Meta analize dâhil edilen çalışmaların toplam örneklem büyüklügünü deney grubunda 286 katılımcl, kontrol grubunda 280 katılımcl olmak üzere 566 öğrenci oluşturmaktadır. Meta analize dâhil edilen çalışmalar heterojen yapıdadır. Huni saçıım grafiğinin yayın yanlıı̆ı̆na ilişkin sonucuna ek olarak Orwin'in Güvenli N analizi, Duval ve Tweedie'nin Kırpma ve Doldurması ve Egger'in regresyon analizi ile yayın yanlılığının olmadığı tespit edilmiştir. Etki değerleri rastgele etkiler modeline göre hesaplanmıştır. Etki değeri hesaplamalarında Cohen'in $d$ katsayısı kullanılmıştır. Araştırmada dijital öykülerin Türkçe dil becerilerinin gelişimi üzerindeki etkisine göre hesaplanan etki değerlerine, öğrenim düzeyi, yayın türü ve beceri alanı değişkenlerinin moderatör değişken etkisi de incelenmiştir. Moderatör değişken etkisinin belirlenmesinde $Q$ testi ve $p$ anlamlıı katsayısı kullanılımıştır. Araştırmada dijital öykülerin Türkçe dil becerilerinin gelişimi üzerinde yüksek düzeyde bir etkisi olduğu tespit edilmiştir. Moderatör değişken analizi sonucu incelendiğinde yayın türü ve beceri alanı moderatör değişkenleri için çalışmalar arası varyansın Türkçe dil becerilerinin gelişimi açısından anlamlı olmadığı; öğrenim düzeyi moderatör değişkeni için ise lisans düzeyi lehine anlamlı olduğu görülmüştür.
\end{abstract}

Anahtar Kelimeler: Türkçe dil becerileri, dijital öykü, meta analiz

\section{The Effect of Digital Stories on the Development of the Turkish Language Skills: A Meta-Analysis Study}

\begin{abstract}
The purpose of the current study is to determine the effect of digital stories on the development of the Turkish language skills of students from different grade levels in Turkey. To this end, a metaanalysis of the studies investigating the effect of digital stories on the development of the Turkish language skills was conducted. 11 studies were included in the current meta-analysis study. The total sample size of the studies included in the meta-analysis is 566 students; 280 in the control groups and 286 in the experimental groups. The studies included in the meta-analysis are heterogonous. In addition to result of the funnel scatter plot related to publication bias, absence of the publication bias was confirmed with Orwin's Safe N Analysis, Duval and Tweedie's Trip and Fill and Egger's regression analysis. Effect sizes were calculated according to the random effects model. In the calculations of the effect sizes, Cohen's $d$ coefficient was used. In the current study, moderator variable effect of the variables of grade level, type of publication and skill area on the effect sizes calculated according to the effect of the digital stories on the development of the Turkish language skills was also examined. In the determination of the moderator variable effect, $Q$ test and $p$ significance coefficient were used. In the current study, digital stories was found to have a high level of effect on the development of the Turkish language skills. When the results of the moderator variable analysis were examined, it was found that for the type of publication and
\end{abstract}

\footnotetext{
* Arş. Gör. Dr., Muğla Sıtkı Koçman Üniversitesi, Eğitim Fakültesi, Türkçe ve Sosyal Bilimler Eğitimi Bölümü, Muğla, gozkaya@mu.edu.tr, ORCID: 0000-0001-9630-9739.
} 
skill area moderator variables, the between-studies variance is not significant in terms of the development of the Turkish language skills while it was found to be significant in favour of the undergraduate level variable for the grade level moderator variable.

Keywords: Turkish language skills, digital story, meta-analysis

\section{Giriş}

Duygu ve düşünceleri aktarma, farklı duygu ve düşünceleri algılama, yorumlama, yeni duygu ve düşünceler üretme sürecini kapsayan çok boyutlu bir ifade ve iletişim aracı olan dil; bireyin kendi dünyasıyla ve dış dünyayla ilişki kurabilmesinin yapı taşıdır. Bu sürecin sağlıklı bir biçimde gerçekleştirilmesini sağlayan temel dil becerileri ise anlama ve anlatma becerileri olarak ele alınmaktadır. Dil eğitiminin temel amacl; anlama becerilerimiz olan dinleme/izleme ve okuma, anlatma becerilerimiz olan konuşma ve yazma becerilerinin doğru ve etkili bir biçimde gelişimini sağlamaktır. Bireylerin iletişim becerilerinin gelişiminin dil becerilerinin gelişimi ile orantılı olduğu göz önünde bulundurulduğunda; dil eğitiminin, bireyin gelişim özellikleri doğrultusunda, anlam ve iletişim boyutuna önem verilerek işlevsel olarak düzenlenmesi oldukça önemlidir.

Türkçe Dersi Öğretim Programı (illkokul ve Ortaokul 1, 2, 3, 4, 5, 6, 7, ve 8. Sınıflar) incelendiğinde Avrupa Yeterlikler Çerçevesi doğrultusunda oluşturulan Türkiye Yeterlikler Çerçevesi kapsamında bireyde olması hedeflenen sekiz temel yetkinliğin belirlendiğini görülmektedir. Bu sekiz temel yetkinlik ilköğretim ve ortaöğretim düzeyindeki bütün öğretim programları için ortak olarak belirlenmiştir. Bunlardan "ana dilde iletişim" yetkinliği "kavram, düşünce, görüş, duygu ve olguları hem sözlü hem de yazılı olarak ifade etme ve yorumlama (dinleme, konuşma, okuma ve yazma); eğitim ve öğretim, iş yeri, ev ve eğlence gibi her türlü sosyal ve kültürel bağlamda uygun ve yaratıcı bir şekilde dilsel etkileşimde bulunmak" şeklinde tanımlanmış; yetkinlik kapsamında dili anlama ve kullanma ihtiyacına değinilmiştir (Milli Eğitim Bakanlı̆̆ı [MEB], 2019). "Dili anlama ve kullanma" yetkinliğine sahip olmak demek, dil becerilerinin gelişiminin sağlıklı olarak tamamlanması, öğrenilen dil yapılarının hayata aktarılabilmesi ve doğru yerde doğru şekilde iletişim kurabilmek demektir. Bu doğrultuda dil becerilerinin gelişimi, üzerinde hassasiyetle durulması gereken önemli bir konu olarak karşımıza çıkmaktadır. Bu bağlamda öğrenilenleri zihinde yapılandııı hayatla ilişkilendirebilen bir yaklaşımın, dil becerilerinin gelişiminin etkili bir biçimde gerçekleşmesine katkı sağlayacağı söylenebilir. Öğrenilenlerin zihinde yapılandırılıp hayatla ilişkilendirilebilmesine olanak sağlayan yöntemlerden biri de "metinle öğrenme"dir. Metinle öğrenme, metindeki bilgilerden yararlanarak çeşitli etkinliklerle öğrencilerin dil becerilerinin geliştirilmesi olarak tanımlanabilir. Metinle öğrenme; zihinde canlandırma, sorgulama, çıkarımda bulunma, günlük hayatla ilişkilendirme ve farklı metinlerle iliş̧i kurma gibi süreçleri içinde barındırmaktadır (Güneş, 2013). Metinle öğrenmenin sağlanabilmesi için bu süreçlerin sağlıklı bir biçimde gerçekleşmesi önemlidir. Bu doğrultuda metinle öğrenmenin temelini oluşturan metin türlerinin seçimi metinle öğrenme sürecini destekleyecek, bu süreci kolaylaştırabilecek ve öğrencilerin ilgisini çekebilecek nitelikte olmalıdır.

Metinle öğrenme bağlamında kullanılabilecek türlerden biri de öykülerdir. Öyküler; zaman, mekân, kişi, olay, durum gibi hayata dair ögeleri içinde barındırması yönüyle öğrencilerin özdeşim kurabilecekleri, metin üzerinde çıkarımda bulunup metne ait ögeleri kendi hayatlarıyla ilişkilendirebilecekleri bir türdür. Bu bakımdan öyküler metinle öğrenme sürecini destekleyici niteliktedir. Carlson, vd. (2000 akt. Dağıstan, 2015), bilgilerin öykü bağlamında sunulmasıyla bilgileri hatırlamanın kolaylaştığını belirtmişlerdir. Öyküler, eğitim öğretim ortamında bir eğitim aracı olarak da kullanılmakta ve öyküleme yönteminin temelini oluşturmaktadır. Bir öykü metni bağlamında bilgilerin sunulduğu, becerilerin kazandırıldığı öyküleme yöntemi, eğitim öğretimde bellek destekleyici bir strateji olarak karşımıza çıkmaktadır. Dağıstan (2015) tarafından yapılan araştırmada, öyküleme yönteminin, kelime bilgisi başarısını ve öğrenilen kelimelerin kalııılığını önemli düzeyde etkilediği tespit edilmiştir. Yılmaz ve Taflan (2010) ise araştırmalarında, öyküleme yönteminin öğrencilerin Türkçe derslerindeki anlama/anlatma düzeyini artırdığını, derse yönelik istek ve katılımlarının artmasına yardımcı olduğunu belirtmişlerdir. Alanyazındaki farklı araştırmalarda da öyküleme yönteminin öğrencilerin akademik başarıları ve motivasyonları üzerinde olumlu etkiye sahip olduğu sonucuna ulaşılmıştır (Demir, 2012; Gürol ve Kerimgil, 2012; Mitchell; 2016; Tepetaş ve Haktanır, 2013). Bu 
sonuçlar öyküleme yönteminin ve öykülerin öğrencilerin dil becerilerinin gelişiminde başarıyı ve motivasyonu arttırdığını göstermektedir.

Öyküleme yönteminin çağın teknolojileriyle harmanlanmasıyla "dijital öyküleme" kavramı ortaya çıkmıştır. Bu kavram "dijital ortamlarda yazılabilen, depolanabilen, yayımlanabilen, okunabilen öyküler" olarak tanımlanabilmektedir (Turgut ve Kışla, 2015, s. 102). Alanyazın incelendiğinde dijital öyküleme ile yapılan tanımların ortak yönü "etkileşimli dijital ortamda, teknolojik araçların yardımıyla metin, ses, görüntü ve müziklerin birkaç dakikalık videolar hâlinde sunulması" olarak kabul edilebilir (Figa, 2004; Meadows, 2003; Miller, 2004; Ohler, 2006; Tatum, 2009). Dijital öyküleme, çoklu ortam oluşturarak farklı duyulara hitap etmesi bakımından eğitim öğretim sürecinde tercih edilebilecek bir yöntemdir. Metin, ses gibi ögelere sahip olması yönüyle dijital öyküleme yönteminin dil becerilerinin gelişiminde de kullanılabilecek bir yöntem olduğu söylenebilir. Kurudayıoğlu ve Bal (2014), anlama ve anlatma sürecinde ne kadar çok duyu harekete geçirilirse o kadar başarılı olunacağına dikkat çekerek dijital öykülemenin ana dili eğitiminde kullanılabilecek bir yöntem olduğunu belirtmişlerdir. Duran ve Ertan-Özen (2017) de dil eğitiminde dijital öyküleme yöntemi kullanılan araştırmaları derleyerek söz konusu yöntemin Türkçe öğretimine uygun bir yöntem olabileceğini ifade etmişlerdir.

Dijital öyküleme, anlama ve anlatma becerilerinin tümüne hitap eden çok boyutlu bir yöntemdir. Dijital öykülemede ilk aşama öykü metnini oluşturma sürecidir. Yöntemin bu aşamasında öğrencilerin metinsellik ölçütlerini göz önünde bulundurarak konu ve amaca uygun bir şekilde öykü metnini oluşturabilmeleri, aynı zamanda yazma becerilerinin gelişimini de olumlu yönde etkilemektedir. İkinci aşama olan yazılan öyküyü gözden geçirip düzenleme sürecinde öğrencilerin sessiz okuma, eleştirel okuma, vb. becerilerinin gelişimi sağlanmaktadır. Dijital öyküyü seslendirme sürecinde dilin kuralları doğrultusunda seslerin doğru oluşturulması, parçalarüstü birimlere (vurgu, ton, ezgi, süre, durak, vb.) dikkat edilerek metnin seslendirilmesi, öğrencilerin sesli okuma becerilerini geliştirmektedir. Öykünün paylaşılması aşamasında öyküyü izleyerek öykünün vermek istediği mesajı algılama sürecinde öğrencilerin dinleme/izleme becerilerine hitap edilmektedir. İzlenen dijital öyküye yönelik fikir alışverişinin yapılması sonucunda ise öğrencilerin dili etkili kullanarak duygu ve düşüncelerini doğru aktarabilmesi sağlanabilir. Bu yönüyle de öğrencilerin konuşma becerilerinin gelişimi desteklenmiş olur. Dijital öyküleme sürecinin her aşaması, dil yapılarını doğru kullanmayı gerektirdiğinden bu yöntem dil bilgisi öğrenimine de katkı sağlamaktadır. Dijital öyküleme sınıf içinde bir yöntem olarak uygulanabileceği gibi eğiticiler tarafından hazırlanan dijital öyküler de birer öğrenme aracı olarak kullanılabilmektedir. Eğitim öğretim etkinliklerinin gerçekleştirilmesinde birden fazla duyuya hitap etmek önem arz etmektedir. Bu bağlamda Paivio tarafından geliştirilen ikili kodlama kuramı, sözel ve sözel olmayan kodlamalar sisteminin yapısal ve işlevsel özelliklerine göre, bilginin işlenmesi, kodlanması ve hatırlanmasına dayanmaktadır. Bu kurama göre sözlü ve görsel içeriğin birlikte sunulması, öğrenmeyi daha verimli duruma getirmektedir. Kodlamada birden fazla kanalın kullanılması, öğrenmede olduğu gibi, öğrenilenin kalıcılığında da etkiyi arttırmaktadır (Aldağ, 2005; Aldağ ve Sezgin, 2002). Eğitimde çoklu ortam oluşturmanın önemi göz önünde bulundurulduğunda öğrencilerin birden fazla duyusuna aynı anda hitap etmesi ve böylece birden fazla öğrenme kanalının aktif olarak kullanılması yönüyle dijital öyküler sınıf içinde etkili birer öğrenme aracı olarak tercih edilebilir. Bütün bu değişkenler dil becerilerinin gelişiminde dijital öykülerin kullanımını önemli hâle getirmektedir. Alanyazında yer alan ana dili ve yabancı dil eğitimine yönelik birçok çalışmada dijital öyküleme uygulamalarının veya araştırmacıların hazırladığı, öğrenme aracı olarak kullanılan dijital öykülerin konuşma (Abdolmanafi-Rokni ve Qarajeh, 2014; Tatlı ve Aksoy, 2017), dinleme (Abidin, PourMohammadi, Souriyavongsa, Tiang ve Kim, 2011; Ciğerci, 2015; Demirbaş, 2019; Türe-Köse, 2019; Verdugo ve Belmonte, 2007), okuma (Adıgüzel ve Kumkale, 2018; Çiftçi, 2019; Özerbaş ve Öztürk, 2017; Şentürk-Leylek, 2018; Yılmaz, Üstündağ, Güneş ve Çalışkan, 2017), yazma (Baki, 2015, 2019; BalamanUçar, 2016; Çıralı, 2014; Dayan, 2017; Demirbaş, 2019; Duman ve Göçen, 2015; Gider, 2019; Gündüz, 2019; Uslu, 2019; Yamaç, 2015; Yılmaz vd., 2017) olmak üzere dil becerilerinin gelişiminin yanı sıra sözcük öğrenimi (Aitkuzhinova-Arslan, Gün ve Üstünel, 2016; Özer, 2016; Yardım, 2011) ve dil becerilerinin gelişimine temel oluşturan dil bilgisi öğretimi (Özkaya, 2017) üzerinde etkili olduğu tespit edilmiştir. Alanyazındaki bu çalışmaların her biri kendi içinde dijital öykülerin dil becerileri üzerinde etkili olduğu sonucuna ulaşmıştır. Ancak bu çalışmalarda dijital öykülerin dil becerilerine etkisinin 
farklılaştığı dikkate alındığında yapılan araştırmaların sonuçlarının bir bütün olarak değerlendirilebilmesi ve genellenebilmesi için bir meta analiz çalışmasına ihtiyaç duyulmaktadır. Alanyazın incelendiğinde dijital öykülerin okul öncesi ve ilkokul öğrencilerinin okuryazarlık becerisine etkisine ilişkin bir meta analiz çalışmasının (Takacs, Swart ve Bus, 2015) yapıldığı görülse de dijital öykülerin Türkçe dil becerilerinin gelişimine etkisine yönelik bir meta analiz çalışmasına ulaşılamamıştır. Bu bağlamda bu çalışmanın amacı, dijital öykülerin Türkiye'de farklı öğrenim düzeylerindeki öğrencilerin Türkçe dil becerilerinin gelişimine etkisinin belirlenmesidir. Bu amaç doğrultusunda dijital öykülerin Türkçe dil becerilerinin gelişimine etkisini inceleyen araştırmaların meta analizi yapılmıştır. Araştırma kapsamında; etki değerlerinin araştırmanın türü, katılımcıların öğrenim düzeyi, beceri alanı moderatör değişkenlerine göre farklılık gösterip göstermediği de belirlenmeye çalışımıştır.

\section{Araştırmanın Modeli}

\section{Yöntem}

Bu çalışmada dijital öykülerin öğrencilerin Türkçe dil becerilerinin gelişimine ilişkin genel etki büyüklüklerinin meta analiz yöntemi ile belirlenmesi amaçlanmıştır. Meta analiz, bir konuyla ilgili yapılan çeşitli çalışmalardan elde edilen nicel sonuçların birleştirilmesiyle etki büyüklüğünün hesaplanarak genel bir sonuca ulaşılması olarak tanımlanabilir (Büyüköztürk, Kılıç-Çakmak, Akgün, Karadeniz ve Demirel, 2018; Cumming, 2012; Dinçer, 2014). Meta analiz çalışmalarının gerçekleştirilebilmesi için kendine özgü birtakım işlem basamaklarının izlenmesi gerekmektedir. Bu işlem basamakları "çalışma konusunun belirlenmesi, çalışma konusu ile ilgili araştırmalara ulaşmak amacıyla alanyazın taramasının yapılması, ulaşılan araştırmaların meta analize dâhil edilme ve hariç tutma ölçütlerinin belirlenmesi, araştırma verilerin kodlanması, yayın yanlıı̆ı̆ının belirlenmesi, istatistiksel model seçiminin yapılması, hetorejenliğin test edilmesi, etki büyüklüklerinin hesaplanması ve elde edilen bulguların yorumlanması" şeklinde sıralanabilir. Bu şekilde meta analize dâhil edilme ölçütlerine uygun araştırma sonuçlarının birleştirilmesi yoluyla bir konu hakkında genellenebilir sonuçlara ulaşılabilmektedir. Meta analiz, araştırma sonuçlarının birleştirilerek genel etki büyüklüğüne ulaşılmasının yanı sıra dâhil edilme ölçütlerine uygun araştırmaların özelliklerinin (yayın türü, araştırmanın yürütüldüğü yer) ve çalışma gruplarının özelliklerinin (cinsiyet, yaş, öğrenim düzeyi vb.) çeşitli parametreler açısından incelenmesine olanak sağlamaktadır.

Herhangi bir çalışmanın meta analiz kapsamına dâhil edilebilmesi için çalışmada istatistiksel bulgulara yer verilmesi gerekmektedir (Büyüköztürk, vd., 2018) çünkü meta analizde bir konuyla ilgili yapılan araştırma sonuçlarının tekrar analiz edilerek bütünleştirilmesi ve yorumlanması söz konusudur. Bu doğrultuda meta analizin nicel araştırma yönteminin doğasına uygun olarak gerçekleştirilen bir analiz yöntemi olduğu söylenebilir. Meta analiz bir konu üzerinde yapılan farklı araştırmaların sonuçlarının bir bütün olarak değerlendirilebilmesine ve genellenebilmesine olanak sağlamaktadır (Card, 2011). Bireysel araştırmalarda görece küçük örnekleme ulaşılabilirken, meta analiz yardımıyla örneklem büyüklükleri birleştirilerek daha genel bulgulara erişilebilir (Akgöz, Ercan ve Kan, 2004; Bakioğlu ve Göktaş, 2018). Meta analizin sahip olduğu bu özellikler araştırmacılara, araştırdıkları konuyla ilgili daha tutarlı ve bütüncül bir sonuca ulaşabilme fırsatı sunar. Alanyazın incelendiğinde dijital öykülerin öğrencilerin Türkçe dil becerilerinin gelişimi üzerindeki etkisini inceleyen farklı çalışmaların olduğu görülmektedir. Ancak ulaşılan araştırmalarda dijital öykülerin öğrencilerin Türkçe dil becerilerine etkisinin düzeylerinin farklılaştığı ve araştırma sonuçlarının bütüncül ifade edilmesine gereklilik olduğu görülmektedir. Bu da bireysel araştırmalardan elde edilen sonuçların meta analize tabi tutularak birleştirilmesi ve genel bir etki büyüklüğüne ulaşılmasıyla mümkündür. Bu nedenle bu araştırmada birbirinden bağımsız olarak gerçekleştirilen dijital öykülerin Türkçe dil becerilerinin gelişimi üzerindeki etkisinin incelendiği araştırma sonuçlarını birleştirmek ve genel bir sonuca ulaşmak amaçlanmıştır. Bu doğrultuda araştırma kapsamında, dijital öykülerin Türkçe dil becerilerinin gelişimi üzerindeki etkisinin incelenmesine yönelik desenlenen araştırmalar incelenmiş ve meta analiz yöntemi ile genel bir etki büyüklüğüne ulaşılmaya çalışıımıştır. Ayrıca dijital öykülerin Türkçe dil becerilerinin gelişimi üzerindeki etkisine ilişkin çalışmalara göre hesaplanan etki büyüklüğündeki farklııklar moderatör değişkenler (öğrenim düzeyi, yayın türü, beceri alanı) aracılığıyla incelenmiştir. 


\section{Verilerin Toplanması}

Araştırmanın verileri 2020 yılı Haziran ayında toplanmıştır. Araştırmada kullanılan çalışmalara ulaşmak için "dijital öyküleme, dijital öykü, dijital öyküleyicilik, dijital hikâye, dijital hikâye anlatımı, eöyküleme, bilgi teknolojilerine dayalı hikâye anlatımı, dil becerileri, Türkçe eğitimi" anahtar kelimeleri ve İngilizce karşılıkları ile Google Akademik, YÖK Ulusal Tez Merkezi, ULAKBiM TR Dizin, ProQuest, ISI veri tabanına giren indeksler ( $\mathrm{SCl}, \mathrm{SCl}$ Expanded, $\mathrm{SSCl}, \mathrm{AHCl}$ ve $\mathrm{ESCl})$, Australian Education Indeks, British Education Indeks, ERIC ve Education Full Text (H. W. Wilson, EBSCOhost) veri tabanlarında tarama yapılmıştır. Bu doğrultuda dijital öykülerin Türkçe eğitiminde, Türkçe dil becerilerinin gelişiminde kullanımına yönelik 14 makale ve 13 lisansüstü tez olmak üzere 27 çalışmaya ulaşılmıştır. Ulaşılan çalışmaların 2014-2019 yılları arasında gerçekleştiği görülmüştür. Bu doğrultuda, ulaşılan çalışmaların meta analize dâhil edilebilmesi için ölçütler belirlenmiştir. Bu ölçütler: (1) Araştırmaların 2014-2019 yılları arasında tamamlanmış lisansüstü tezler ile hakemli dergilerde yayınlanmış makaleler olması, (2) Araştırmaların dijital öykülerin Türkçe dil becerilerine etkisini belirlemeye yönelik olması, (3) Deney ve kontrol gruplu (yarı) deneysel araştırmalar olması, (4) Deney grubundaki katılımcılara dijital öyküleme uygulamalarının yaptırılması ya da öğretim aracı olarak araştırmacılar tarafından geliştirilen dijital öykülerin kullanılması; kontrol grubundaki katılımcılara geleneksel öğretim yöntemlerinin uygulanması, (5) Araştırmada dijital öykülerin Türkçe dil becerilerinin gelişimine etkisini belirlemeye yönelik veri toplama araç(lar)ı kullanılması, (6) Araştırmada deney ve kontrol grubunu oluşturan katılımcı sayılarına yer verilmiş olması, (7) Araştırma bulgularında aritmetik ortalama, standart sapma, p değerlerinin ya da etki büyüklüğü hesaplamaları yapılabilmesi için gerekli istatistiklerin raporlanması olarak belirlenmiştir. Bu ölçütler aynı zamanda hariç tutma ölçütleri olarak da kullanılmıştır. Veriler toplanırken lisansüstü tezlerden üretilen makalelere ulaşılması durumunda, daha fazla veri içerdiği ve yayın yanlılığı olasılığının görece düşük olduğu öngörüsüyle lisansüstü tezler meta analize dâhil edilmiştir.

Meta analiz çalışmasına dâhil edilme ölçütleri doğrultusunda 5 araştırma tezden üretilen makale olması, 4 araştırma tek gruplu (yarı) deneysel araştırma olması, 3 araştırma nitel araştırma yöntemleriyle desenlenmesi, 2 araştırma dijital öykülerin Türkçe eğitiminde kullanımına yönelik genel bilgi verici nitelikte olması, 1 araştırma beceri gelişimi yerine öz yeterlik, kaygı ve duyarlılığa yönelik veriler içermesi, 1 araştırma ise gerekli hesaplamaların yapılması için istenen değerlerin raporlanmaması sebebiyle meta analize dâhil edilmemiştir. Sonuç olarak dâhil edilme ölçütlerini karşılayan 11 çalışma ile meta analiz gerçekleştirilmiştir. Meta analize dâhil edilen çalışmaların toplam örneklem büyüklüğünü deney grubunda 286 katılımcı, kontrol grubunda 280 katılımcı olmak üzere 566 öğrenci oluşturmaktadır.

\section{Verilerin Kodlanması}

Belirlenen meta analize dâhil edilme ölçütleri doğrultusunda, araştırmaya dâhil edilecek çalışmalara yönelik bir kodlama formu oluşturulmuştur. Bu forma, çalışmanın adı, yazarı/yazarları, yayın yılı, yayın türü, beceri alanı, öğrenim düzeyi, deney ve kontrol grubu katılımcı sayıları, ön test-son test aritmetik ortalama, standart sapma, p değerlerine yönelik bilgiler kodlanmıştır. Yapılan kodlamanın güvenirliğini sağlamak amacıyla, araştırmacının haricinde iki alan uzmanının araştırma verilerini kodlamaları sağlanmış; yapılan uzlaşı toplantıları sonucunda kodlamalar üzerinde tam görüş birliğinin sağlandığı görülmüştür.

\section{Yayın Yanlılı̆̆ı}

Yayın yanlılı̆̆ı, yayınlanmış çalışmaların o konuda yapılmış tüm çalışmaları sistematik olarak temsil etmemesi olarak tanımlanabilir (Rothstein, Sutton ve Borenstein, 2005). Sadece belirli bir sonuca odaklanılarak ya da alanyazının sınırlı bir şekilde taranmasıyla elde edilen çalışmaların meta analize dâhil edilmesi yayın yanlılı̆ını meydana getiren başlıca sebeplerdir (Dinçer, 2014). Meta analiz çalışmalarında yayın yanlılığı geçerliği tehdit eden önemli bir unsurdur (Sutton, 2009). Bu nedenle etki büyüklükleri belirlenmeden önce, meta analize dâhil edilen çalışmalarda yayın yanlılığının durumu belirlenmiştir. Araştırmada yayın yanlılığının durumu, huni saçılım grafiği, Orwin'in Güvenli N analizi, Duval ve Tweedie'nin Kırpma ve Doldurma analizi ve Egger'in regresyon testi ile incelenmiştir. Bu 
çerçevede bu meta analiz çalışmasında yayın yanlıı̆̆ı olasılığını gösteren huni saçııım grafiği Şekil 1'de gösterilmiştir.

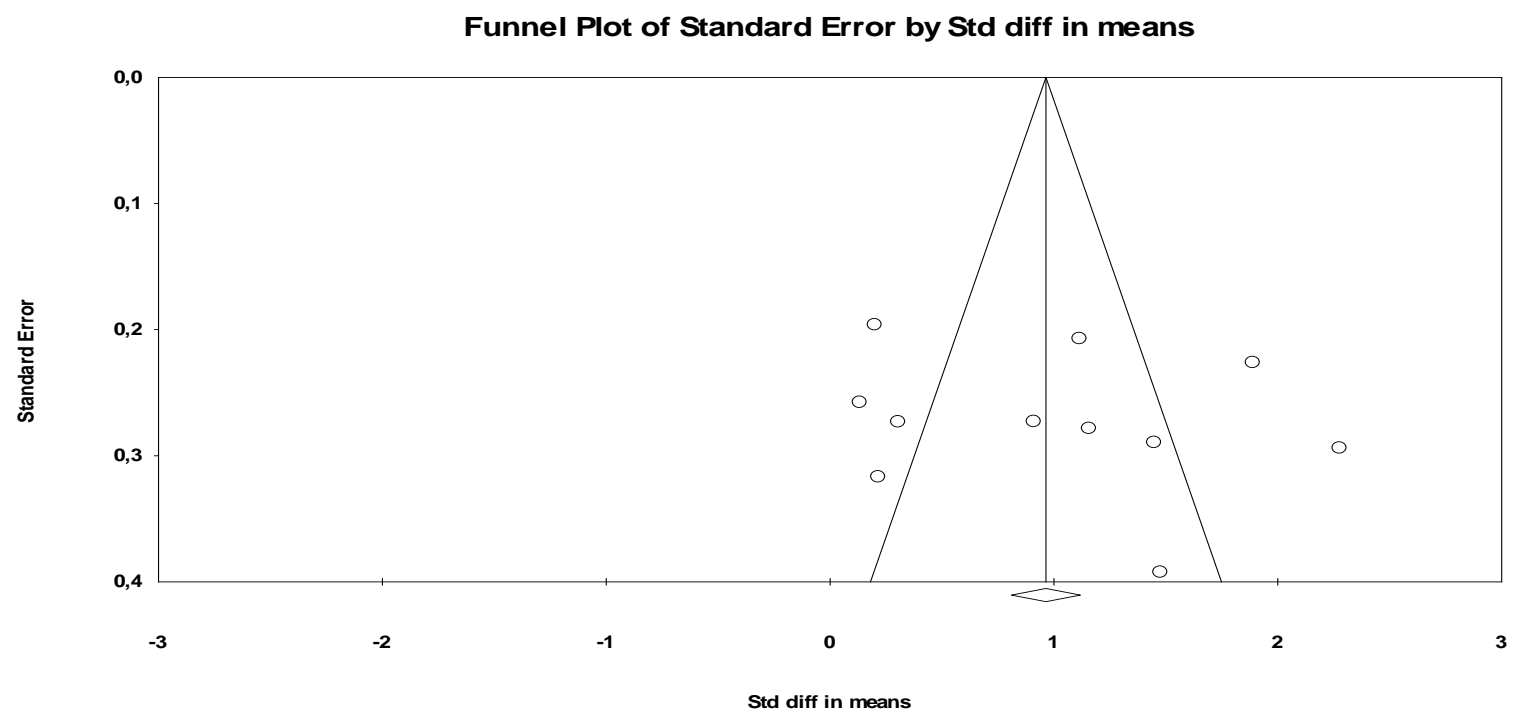

Şekil 1. Dijital Öyküleme Yönteminin Türkçe Dil Becerilerinin Gelişimine Etkisine İlişkin Huni Saçılım Grafiği

Şekil 1'deki huni saçılım grafiği incelendiğinde, çalışmaların genellikle orta bölümde toplandığı ve birleştirilmiş etki büyüklüğünü gösteren dikey çizginin her iki yanına simetrik dağıldığı görülmektedir. Meta analize dâhil edilen çalışmaların etki büyüklüğü ekseni etrafında simetrik biçimde dağılması ve standart hata ekseninin orta ve üst bölümlerinde toplanması yayın yanlıı̆̆ının olasılığının düşüklüğüne işaret etmektedir. Ancak yayın yanlııı̆ının olasılığını görsel olarak sunan huni saçılım grafiğinin ürettiği sonuçlar sınırlıdır. Bu nedenle, huni saçıım grafiğinin yayın yanlılı̆ına ilişkin sonucuna ek olarak Orwin'in Güvenli N analizi, Duval ve Tweedie'nin Kırpma ve Doldurması ve Egger'in regresyon analizi ile de yayın yanlılı̆ının olasılığı incelenmiştir. Elde edilen bulgular Tablo 1'de sunulmuştur.

Tablo 1.

Yayın yanlılı̆ının olasılığına ilişkin güven testleri

\begin{tabular}{cccc}
\hline Orwin Güvenli N & \multicolumn{2}{c}{ Duval ve Tweedie } & Egger Testi \\
$\begin{array}{c}(-/+.01 \text { S.O.F) Gerekli } \\
\text { Çalışma* }\end{array}$ & Kırpılan & Gözlenen/Eklenen & (p) \\
\hline 1050 & 0 & $1.010(1.010)$ & .541 \\
\hline
\end{tabular}

*Cohen'in $d$ katsayısının +/-.01 aralığı dışında bir değere ulaşması için gerekli çalışma sayısı

Tablo 1'e göre Orwin'in Güvenli $N$ analizi sonucunda ulaşılması gereken çalışma sayısının fazlalığı yayın yanlılı̆ııın düşüklüğüne işaret etmektedir. Bu da Cohen'in $d$ katsayısını "önemsiz" olarak kabul edilen +/-.01 aralığı dışında bir değere getirmek için meta analize yeni araştırma eklenmesine gereksinim olmadığını göstermektedir. Duval ve Tweedie testinin sonucu ise yayın yanlılı̆ını olumsuz etkileyen çalışmaların meta analizden çıkarılması veya simetrik karşılıklarının meta analize eklenmesi sonucunda oluşan etki değerlerinin gözlenen değerlerden farklılaşmadığını göstermektedir. Ek olarak, Egger testinin sonucunun anlamlı olmaması ( $p>.05)$ da araştırmada yayın yanlılığının olmadığını doğrulamaktadır.

\section{Model Seçimi}

Meta analiz çalışmasında, çalışmaların örneklem özellikleri, çalışmalar arası varyansın farklılaşma derecesi ve etki tahminlerinin dağılımı göz önünde bulundurularak istatistiksel model seçimi yapılması gerekmektedir. Bu modeller sabit etki modeli ve rastgele etkiler modeli olarak ikiye 
ayrılır. Sabit etkiler modeli, çalışma evren büyüklüklerinin aynı olduğunu ve bu sebeple standart sapmalarının eşit olduğunu kabul ederken rastgele etkiler modeli çalışma evren büyüklüklerinin farklı olduğunu ve standart sapmanın sıfıra eşit olmadığını ifade etmektedir (Dinçer, 2014). Meta analiz çalışmalarında katılımcıların yaşı, eğitim düzeyi gibi özelliklerin farklılaşmasından dolayı etki büyüklüğünün değişebileceği varsayımından hareketle rastgele etkiler modelinin seçilmesi önerilmektedir (Borenstein, Hedges, Higgins ve Rothstein, 2009). Bu meta analiz çalışmasında birleştirilen çalışmaların kapsamı, katıımcı özellikleri gibi hususların farklılaşması sebebiyle rastgele etkiler modelinin kullanılması uygun görülmüştür. Heterojenlik testleri ise birleştirilen çalışmaların heterojen yapıda olduğuna delil sunmak amacıyla kullanılmıştır.

\section{Heterojenlik}

Araştırmada etki büyüklüklerinin heterojen bir dağılım gösterip göstermediğini tespit etmek için heterojenlik testleri yapılmıştır. Meta analize dâhil edilen çalışmaların etki büyüklüklerine ait heterojenlik çoğunlukla $Q$ testi ile tespit edilmektedir. $Q$ testi, birleştirilen etki büyüklüklerindeki heterojenlik olasılığına yönelik bilgi vermesine rağmen heterojenliğin büyüklüğüne yönelik yeterince delil sunmamaktadır (Card, 2011; Huedo-Medina, Sanchez-Meca, Marin-Martinez ve Botella, 2006). Bu nedenle araştırmada heterojenliğin büyüklüğünün belirlenmesinde $I^{2}$ değeri referans alınmıştır. $I^{2}$ değerinin $\% 25$ ve altında olması düşük, \%50 olması orta, \%75 ve üzerinde olması yüksek düzeyde heterojenlik olarak değerlendirilmektedir (Card, 2011; Pigott, 2012). Buna göre Q değeri, $78.655\left(s d_{(Q)}=\right.$ 10; $p=.000$ ) olarak hesaplanmıştır. $I^{2}$ değeri ise 87.286 olarak belirlenmiştir. Bu değerler meta analize dâhil edilen çalışmaların yüksek düzeyde heterojen olduğunu göstermektedir. Meta analize dâhil edilen çalışmaların yüksek düzeyde heterojen yapıda olması etki büyüklükleri arasındaki farklılıklarını inceleme gereksinimi doğurmaktadır. Bu doğrultuda dijital öykülerin Türkçe dil becerilerinin gelişimi üzerindeki etkisine ilişkin çalışmalara göre hesaplanan etki büyüklüğündeki farklılıklar moderatör değişkenler aracılığıyla incelenmiştir.

\section{Etki Büyüklüklerinin Hesaplanması}

Meta analiz çalışmasında etki değeri hesaplamalarında Cohen'in $d$ katsayısı kullanılmıştır. Etki değerine ilişkin tüm hesaplamalarda güven düzeyi \%95 olarak kabul edilmiştir. Cohen'in $d$ katsayısının $\mathrm{d}<.20$ olması düşük düzeyde etki, $.20 \leq \mathrm{d}<.50$ olması orta düzeyde etki ve $50 \leq \mathrm{d}$ olması yüksek düzeyde etki olduğunu göstermektedir (Cohen, 1988).

Araştırmada dijital öyküleme yönteminin Türkçe dil becerilerinin gelişimi üzerindeki etkisine göre hesaplanan etki değerlerine, öğrenim düzeyi, yayın türü ve beceri alanı değişkenlerinin moderatör değişken etkisi de incelenmiştir. Moderatör değişken etkisinin belirlenmesinde $Q$ testi ve $p$ anlamlılık katsayısı kullanılmıştır. 


\section{Meta Analize Dâhil Edilen Çalışmaların Özelliklerine Yönelik Bulgular}

\section{Bulgular}

Meta analize dâhil edilen çalışmaların sahip olduğu özelliklere yönelik bulgular Tablo 2'de sunulmuştur.

Tablo 2 .

Meta analize dâhil edilen çalıșmalara iliskin betimsel bilgiler

\begin{tabular}{|c|c|c|c|c|c|c|c|c|c|c|c|c|}
\hline $\begin{array}{l}\text { Yazar } \\
\text { adı/yayın } \\
\text { yılı }\end{array}$ & Yayın türü & Beceri alanı & $\begin{array}{l}\text { Öğrenim } \\
\text { düzeyi }\end{array}$ & $\overline{\mathrm{X}}_{\text {Deney }}$ & SDeney & $\mathrm{n}_{\text {Deney }}$ & $\overline{\mathrm{X}}_{\text {Kontrol }}$ & SKontrol & $\mathrm{n}_{\text {Kontrol }}$ & $\mathrm{p}$ & Cohen's d & Shata \\
\hline $\begin{array}{l}\text { Baki } \\
\text { (2015) }\end{array}$ & Doktora tezi & Yazma & Ortaokul & 157 & 26.040 & 30 & 141.370 & 157 & 30 & - & .139 & .259 \\
\hline $\begin{array}{l}\text { Ciğerci } \\
\text { (2015) }\end{array}$ & Doktora tezi & Dinleme & illkokul & 32.170 & 2.990 & 30 & 27.800 & 4.390 & 30 & - & 1.164 & .279 \\
\hline $\begin{array}{l}\text { Çıralı } \\
\text { (2014) }\end{array}$ & Yüksek lisans tezi & Yazma & illkokul & 29.140 & 6.370 & 30 & 24.030 & 4.610 & 29 & - & .917 & .274 \\
\hline $\begin{array}{l}\text { Çiftçi } \\
\text { (2019) }\end{array}$ & Yüksek lisans tezi & Okuma & illkokul & 8.080 & 3.630 & 26 & 7.070 & 2,850 & 28 & - & .311 & .274 \\
\hline $\begin{array}{l}\text { Demirbaş } \\
\text { (2019) }\end{array}$ & Yüksek lisans tezi & Dinleme & îlkokul & .648 & .204 & 26 & .627 & .149 & 26 & - & .118 & .278 \\
\hline $\begin{array}{l}\text { Demirbaş } \\
\text { (2019) }\end{array}$ & Yüksek lisans tezi & Yazma & ilkokul & 3.144 & .910 & 26 & 2.880 & .880 & 26 & - & .295 & .279 \\
\hline $\begin{array}{l}\text { Duman ve } \\
\text { Göçen } \\
(2015)\end{array}$ & Makale & Yazma & Lisans & 30.340 & 6.530 & 38 & 17.550 & 4.490 & 38 & - & 2.282 & .295 \\
\hline $\begin{array}{l}\text { Gider } \\
\text { (2019)a }\end{array}$ & Yüksek lisans tezi & $\begin{array}{l}\text { Yazma } \\
\text { (cümle } \\
\text { akıcılığı) }\end{array}$ & illkokul & 9 & - & 7 & 3 & - & 5 & .004 & 2.176 & .735 \\
\hline $\begin{array}{l}\text { Gider } \\
\text { (2019)a }\end{array}$ & Yüksek lisans tezi & $\begin{array}{l}\text { Yazma } \\
\text { (düzenleme) }\end{array}$ & illkokul & 9 & - & 7 & 3 & - & 5 & .004 & 2.176 & .735 \\
\hline
\end{tabular}




\section{Dijital Öykülerin Türkçe Dil Becerilerinin Gelişimine Etkisi: Bir Meta Analiz Çalışması}

\begin{tabular}{|c|c|c|c|c|c|c|c|c|c|c|c|c|}
\hline $\begin{array}{l}\text { Gider } \\
\text { (2019)a }\end{array}$ & Yüksek lisans tezi & $\begin{array}{l}\text { Yazma (fikir- } \\
\text { içerik) }\end{array}$ & İlkokul & 8.860 & - & 7 & 3.200 & - & 5 & .007 & 1.979 & .711 \\
\hline $\begin{array}{l}\text { Gider } \\
\text { (2019)a }\end{array}$ & Yüksek lisans tezi & $\begin{array}{l}\text { Yazma } \\
\text { (yazma } \\
\text { kuralları) }\end{array}$ & İlkokul & 8.930 & - & 7 & 3.100 & - & 5 & .005 & 2.097 & .725 \\
\hline $\begin{array}{l}\text { Gider } \\
\text { (2019)a }\end{array}$ & Yüksek lisans tezi & $\begin{array}{l}\text { Yazma } \\
\text { (yazma } \\
\text { performansı) }\end{array}$ & İlkokul & 9 & - & 7 & 3 & - & 5 & .004 & 2.176 & .735 \\
\hline $\begin{array}{l}\text { Gider } \\
\text { (2019)b }\end{array}$ & Yüksek lisans tezi & $\begin{array}{l}\text { Yazma } \\
\text { (cümle } \\
\text { akıcılığı) }\end{array}$ & İlkokul & 8.500 & - & 6 & 3 & - & 5 & .006 & 2.163 & .761 \\
\hline $\begin{array}{l}\text { Gider } \\
\text { (2019)b }\end{array}$ & Yüksek lisans tezi & $\begin{array}{l}\text { Yazma } \\
\text { (düzenleme) }\end{array}$ & İlkokul & 8.170 & - & 6 & 3.400 & - & 5 & .017 & 1.769 & .713 \\
\hline $\begin{array}{l}\text { Gider } \\
\text { (2019)b }\end{array}$ & Yüksek lisans tezi & $\begin{array}{l}\text { Yazma (fikir- } \\
\text { içerik) }\end{array}$ & İlkokul & 7.670 & - & 6 & 4 & - & 5 & .068 & 1.255 & .662 \\
\hline $\begin{array}{l}\text { Gider } \\
\text { (2019)b }\end{array}$ & Yüksek lisans tezi & $\begin{array}{l}\text { Yazma } \\
\text { (yazma } \\
\text { kuralları) }\end{array}$ & ilkokul & 7.830 & - & 6 & 3.800 & - & 5 & .039 & 1.462 & .681 \\
\hline $\begin{array}{l}\text { Gider } \\
\text { (2019)b }\end{array}$ & Yüksek lisans tezi & $\begin{array}{l}\text { Yazma } \\
\text { (yazma } \\
\text { performansı) }\end{array}$ & İlkokul & 8.330 & - & 6 & 3.200 & - & 5 & .011 & 1.932 & .732 \\
\hline $\begin{array}{l}\text { Özerbaş } \\
\text { ve Öztürk } \\
\text { (2017) }\end{array}$ & Makale & Okuma & Ortaokul & 75.250 & 7.370 & 16 & 50.310 & 22.310 & 17 & - & 1.482 & .393 \\
\hline $\begin{array}{l}\text { Özkaya } \\
\text { (2017) }\end{array}$ & Doktora tezi & Dil bilgisi & Ortaokul & 60.660 & 23.010 & 21 & 55.310 & 25.310 & 19 & - & .222 & .318 \\
\hline $\begin{array}{l}\text { Uslu } \\
\text { (2019) }\end{array}$ & Yüksek lisans tezi & Yazma & İlkokul & 28.070 & 5.050 & 30 & 21.170 & 4.420 & 30 & - & 1.454 & .290 \\
\hline $\begin{array}{l}\text { Yılmaz vd. } \\
\text { (2017) }\end{array}$ & Makale & Okuma & Ortaokul & 37.230 & 11.260 & 26 & 28.960 & 5.870 & 28 & - & .931 & .287 \\
\hline
\end{tabular}




\begin{tabular}{|c|c|c|c|c|c|c|c|c|c|c|c|}
\hline $\begin{array}{l}\text { Yılmaz vd. Makale } \\
\text { (2017) }\end{array}$ & Yazma & Ortaokul & 102.310 & 9.900 & 26 & 79.680 & 21.600 & 28 & - & 1.330 & .301 \\
\hline
\end{tabular}

$\overline{\mathrm{X}}$ : Aritmetik ortalama; n: Örneklem büyüklügü; S: Standart sapma; $p<.05$; Cohen's $d$ : Etki büyüklüğ̈̈; Shata: Standart hata

Tablo 2 incelendiğinde 3'ü doktora tezi (\%27), 5’i yüksek lisans tezi (\%46) ve 3'ü makale (\%27) olmak üzere toplam 11 çalışmanın meta analize dâhil edildiği görülmektedir. Bu çalışmaların 6'sı ilkokul (\%55), 4'ü ortaokul (\%36) ve 1'i ise lisans (\%9) düzeyinde öğrenim gören katılımcılarla gerçekleştirilen çalışmalardır. Çalışmaların yapııdığı yıllara göre dağııımı incelendiğinde, 2014 yılına ait 1 (\%9), 2015 yılına ait 3 (\%27), 2017 yııına ait 3 (\%27) ve 2019 yılına ait 4 (\%36) çalışmanın yer aldığı görülmektedir. Meta analize dâhil edilen çalışmaların 6’sında (\%55) araştırmacılar tarafından hazırlanan dijital öyküler öğrenme aracı olarak kullanılırken 5'inde (\%45) katııımcılara dijital öyküleme uygulamaları yaptırılmıştır. Meta analize dâhil edilen çalışmalar dijital öykülerin etkisinin ölçüldüğü beceri alanlarına göre incelendiğinde, çalışmaların bazılarının birden fazla beceri alanına yönelik olduğu görülmektedir. Bu sebeple bu çalışmalar, inceledikleri her iki beceri alanının sayılarına da eklenmiştir. Bu doğrultuda araştırmada dinleme becerisine yönelik 2 çalışmanın (\%15), okuma becerisine yönelik 3 çalışmanın (\%23), yazma becerisine yönelik 7 çalışmanın (\%54) ve dil bilgisi öğretimine yönelik 1 çalışmanın (\%8) yer aldığı söylenebilir. Ayrıca bir çalışmada (Gider, 2019) katılımcıların yazma becerisine ait puanları iki deney bir kontrol grubu olarak ayrı ayrı alt başlıklar altında değerlendirilmiş; genel bir yazma puanı verilmemiştir. Bu çalışma meta analize dâhil edilirken öncelikle birinci deney grubu ve kontrol grubunun verileri (Gider2019a), ikinci deney grubu ve kontrol grubunun verileri (Gider2019b) olarak Cohen's $d$ and standard hata değerleri hesaplanarak birleştirilmiş; sonrasında genel etki büyüklüğü elde edilmiştir. 


\section{Dijital Öykülerin Türkçe Dil Becerilerinin Gelişimine Etkisine Yönelik Bulgular}

Araştırmanın amacı dijital öykülerin Türkçe dil becerilerinin gelişimine etkisini belirlemektir. Bu doğrultuda dijital öykülerin Türkçe dil becerilerinin gelişimine etkisine ilişkin orman grafiği şekil 2'de; etki büyüklüğüne yönelik istatistikler Tablo 3'te sunulmuştur.

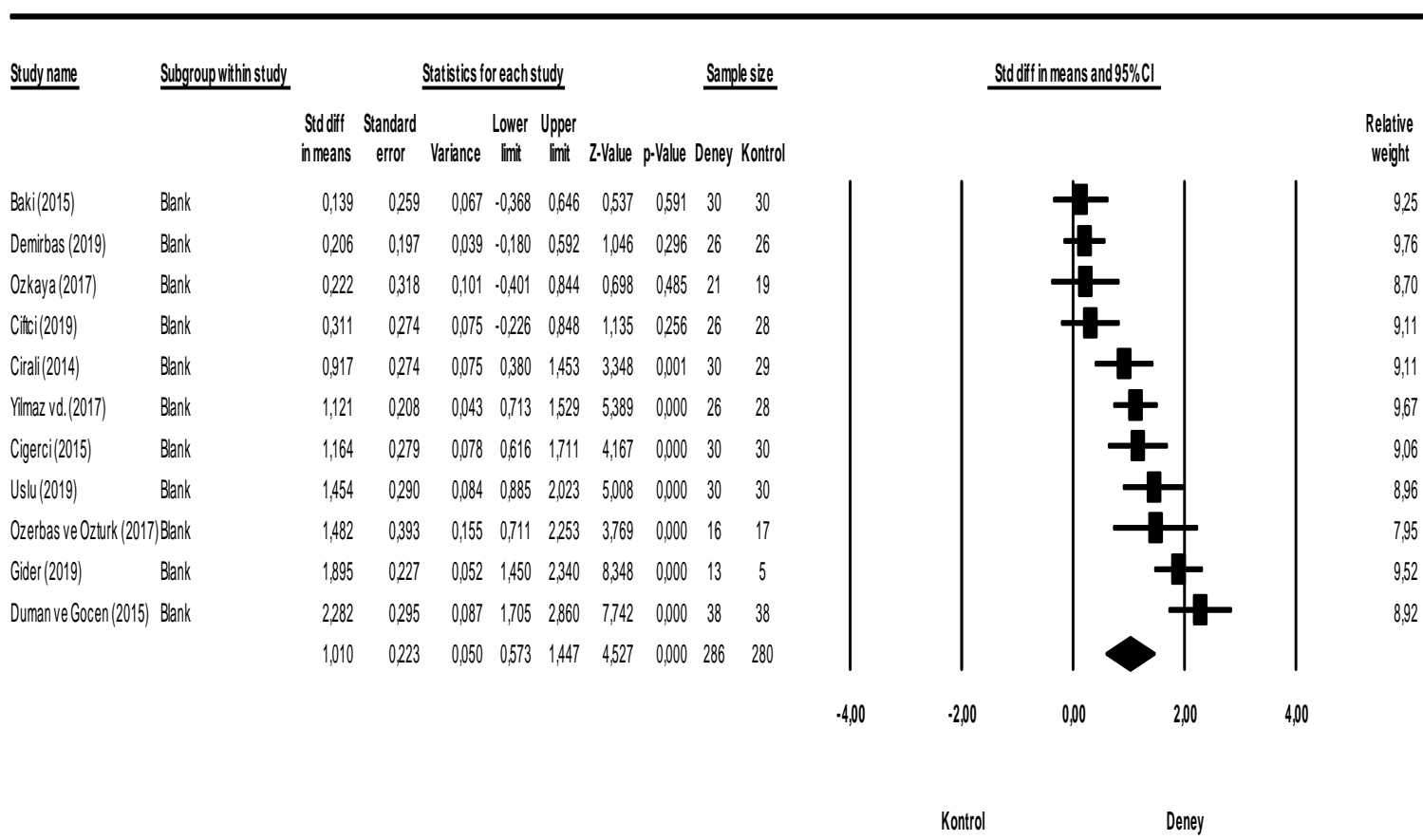

Şekil 2. Dijital Öykülerin Türkçe Dil Becerilerinin Gelişimine Etkisine Iliş̧kin Orman Grafiği

Tablo 3.

Dijital öykülerin Türkçe dil becerilerinin gelişimine etkisine ilişkin analiz sonucu

\begin{tabular}{llllllll}
\hline $\mathbf{k}$ & $\mathbf{n}$ & $\mathbf{E B}_{\text {ort }}$ & $\boldsymbol{p}$ & $\mathbf{z}$ & Shata & $\mathbf{E B}_{\text {alt }}$ & $\mathbf{E B}_{\text {üst }}$ \\
\hline 11 & 566 & 1.010 & .000 & 4.527 & .223 & .573 & 1.447 \\
\hline
\end{tabular}

k: Meta analize dâhil edilen çalışma sayısı; n: Örneklem büyüklüğü; EBort: Ortalama etki büyüklüğü; Shata: Standart hata; $E_{\text {alt }}-E_{\text {üst: }}$ Etki büyüklüğünün alt ve üst sınırları

Şekil 2'ye göre meta analize dâhil edilen araştırmaların tümünde deney grubu yönünde pozitif etkiler gözlemlenmektedir. Ayrıca analize dâhil edilen çalışma ağırlıkları birbirine yakın durumdadır. Çalışma ağırııları açısından bu benzerlik, birleştirilen çalışmaların genel etki büyüklügüne katkısının benzer olduğunu göstermektedir. Meta analize dâhil edilen çalışmaların etki büyüklükleri incelendiğinde ise etki büyüklüğü en yüksek olan çalışmanın Duman ve Göçen'e (2015); en düşük olan çalışmanın Baki'ye (2015) ait olduğu görülmektedir.

Şekil 2 ve Tablo 3 birlikte değerlendirildiğinde, dijital öykülerin Türkçe dil becerilerinin gelişimine etkisini incelemeye yönelik 11 çalışma ile yapılan meta analiz sonuçlarına göre dijital öykülerin Türkçe dil becerilerinin gelişimi üzerindeki etki değerinin 1.010 ( $p>.05)$, etki büyüklüğünün standart hatasının .223 olduğu görülmüştür. Bu değerler genel etki büyüklüğünün pozitif yönde ve yüksek düzeyde olduğunu göstermektedir. Meta analiz çalışmasının bulguları, dijital öyküleme yöntemi uygulanan veya dijital öykülerin öğrenme aracı olarak kullanıldığı deney grubu öğrencilerinin Türkçe dil becerilerinin gelişiminin geleneksel yöntemler uygulanan kontrol grubu öğrencilerinin Türkçe dil becerilerinin gelişiminden daha yüksek olduğunu ortaya koymaktadır. 


\section{Moderatör Değişkenlere Göre Dijital Öykülerin Türkçe Dil Becerilerinin Gelişimine Etkisine Yönelik Bulgular}

Araştırmanın genel amacı doğrultusunda, dijital öykülerin Türkçe dil becerilerinin gelişimine etkisinin, öğrenim düzeyi, yayın türü ve beceri alanına göre farklılık gösterip göstermediği incelenmiştir. Elde edilen bulgular Tablo 4'te sunulmuştur.

Tablo 4.

Moderatör değişkenlere göre dijital öykülerin Türkçe dil becerilerinin gelişimine etkisine ilişkin analiz sonucu

\begin{tabular}{|c|c|c|c|c|c|c|c|c|}
\hline $\begin{array}{l}\text { Moderatör } \\
\text { değişken }\end{array}$ & $\begin{array}{l}\text { Moderatör } \\
\text { değişken düzeyleri }\end{array}$ & $\mathrm{k}$ & $\mathrm{EB}_{\text {ort }}$ & $\mathrm{EB}_{\text {alt }}$ & EBüst & sd & $Q$ & $p$ \\
\hline Öğrenim & illkokul & 6 & .987 & .411 & 1.563 & 2 & 15.441 & .000 \\
\hline \multirow[t]{2}{*}{ düzeyi } & Ortaokul & 4 & .722 & .100 & 1.344 & & & \\
\hline & Lisans & 1 & 2.282 & 1.705 & 2.860 & & & \\
\hline \multirow[t]{3}{*}{ Yayın türü } & Doktora tezi & 3 & .510 & -.148 & 1.168 & 2 & 4.719 & .094 \\
\hline & Yüksek lisans tezi & 5 & .953 & .267 & 1.640 & & & \\
\hline & Makale & 3 & 1.616 & .865 & 2.368 & & & \\
\hline \multirow[t]{4}{*}{ Beceri alanı } & Dinleme & 2 & .640 & -.385 & 1.665 & 3 & 4.987 & .173 \\
\hline & Okuma & 3 & .863 & .228 & 1.498 & & & \\
\hline & Yazma & 7 & 1.186 & .590 & 1.782 & & & \\
\hline & Dil bilgisi & 1 & .222 & -.401 & .844 & & & \\
\hline
\end{tabular}

Tablo 4'te yer alan moderatör değişken analizi sonucu incelendiğinde, yayın türü (doktora tezi, yüksek lisans tezi, makale) ve beceri alanı (dinleme, okuma, yazma, dil bilgisi) moderatör değişkenleri için çalışmalar arası varyansın Türkçe dil becerilerinin gelişimi değişkeni açısından anlamlı olmadığı görülmektedir ( $p>05$ ). Ancak öğrenim düzeyi (ilkokul, ortaokul, lisans) moderatör değişkeni için çalışmalar arası varyans Türkçe dil becerilerinin gelişimi açısından anlamlıdır (Qöğrenim düzeyi=15.441 $s d=2 ; p<.05$ ). Buna göre, çalışmaların farklı öğrenim düzeylerinde yapılmış olması Türkçe dil becerilerinin gelişimine göre hesaplanan etki büyüklüğünü değiştirmektedir. Etki büyüklüklerinin ortalamaları incelendiğinde, öğrenim düzeyi bakımından lisans düzeyinde yapılan çalışmaların Türkçe dil becerilerinin gelişimi üzerindeki etkisinin daha yüksek olduğu görülmektedir. Bu sonuçların dijital öyküleme yöntemi uygulanan veya dijital öykülerin öğrenme aracı olarak kullanıldığı deney grubu öğrencilerinin lehine olduğu ifade edilebilir.

\section{Tartışma ve Sonuç}

Dijital öykülerin Türkiye'de farklı öğrenim düzeylerindeki öğrencilerin Türkçe dil becerilerinin gelişimine etkisinin belirlenmesinin amaçlandığı bu meta analiz çalışmasına, 11 araştırma dâhil edilmiş ve araştırmaların etki büyüklükleri hesaplanmıştır. Meta analize dâhil edilen çalışmaların örneklem büyüklüğü deney grubunda 286 katılımcı, kontrol grubunda 280 katılımcı olmak üzere toplam 566 kişidir. Alanyazında dijital öykülerin Türkiye'de farklı öğrenim düzeylerindeki öğrencilerin Türkçe dil becerilerinin gelişimine etkisine yönelik bir meta analiz çalışmasına ulaşılamaması, bu araştırmanın önemini ortaya çıkarmaktadır. Araştırmada dijital öykülerin Türkçe dil becerilerinin gelişimine etkisini inceleyen çalışmaların meta analizi yapılmıştır. Araştırma kapsamında; etki değerlerinin araştırmanın türü, katılımcıların öğrenim düzeyi, beceri alanı moderatör değişkenlerine göre farklılık gösterip göstermediği de belirlenmiştir.

11 çalışma ile yapılan meta analiz sonuçlarına göre dijital öykülerin Türkçe dil becerilerinin gelişimi üzerinde yüksek düzeyde bir etkisi olduğunu görülmektedir. Etki değerleri ve orman grafiği birlikte değerlendirildiğinde, dijital öyküleme yöntemi uygulanan veya dijital öykülerin öğrenme aracı olarak kullanıldığı deney grubu öğrencilerinin Türkçe dil becerilerinin gelişiminin geleneksel yöntemler uygulanan kontrol grubu öğrencilerinin Türkçe dil becerilerinin gelişiminden daha yüksek olduğu görülmektedir. Bu sonuç, dijital öykülerin öğrencilerin Türkçe dil becerilerinin gelişiminde etkili olduğunu göstermektedir. Takacs, Swart ve Bus (2015) tarafından yapılan meta analiz çalışmasında 
dijital öyküleme yönteminin okul öncesi ve ilkokul öğrencilerinin okuryazarlık becerisine etkisi incelenmiş ve çoklu ortam özellikleri eklenerek okunan elektronik kitapların geleneksel olarak öykü kitabı ile okunan hikâye kitaplarına göre okuryazarlık becerisi üzerinde daha etkili olduğu sonucuna ulaşılmıştır. Bu sonuç araştırmanın sonucuyla benzerlik göstermektedir. Ayrıca Duran ve Özen (2017), dil eğitiminde dijital öyküleme yöntemi kullanılan araştırmaları derleyerek söz konusu yöntemin Türkçe öğretimine uygun bir yöntem olabileceğini ifade etmişlerdir. Benzer şekilde Kurudayıoğlu ve Bal (2014) da anlama ve anlatma sürecinde ne kadar çok duyu harekete geçirilirse o kadar başarılı olunacağına dikkat çekerek dijital öykülemenin ana dili eğitiminde kullanılabilecek bir yöntem olduğunu belirtmişlerdir. Bütün bu çalışmalar, araştırmadan elde edilen sonucu destekler niteliktedir.

Araştırmanın genel amacı doğrultusunda dijital öykülerin Türkçe dil becerilerinin gelişimine etkisinin öğrenim düzeyi, yayın türü ve beceri alanına göre farklılık gösterip göstermediği de incelenmiştir. Moderatör değişken analizi sonucu incelendiğinde yayın türü (doktora tezi, yüksek lisans tezi, makale) ve beceri alanı (dinleme, okuma, yazma, dil bilgisi) moderatör değişkenleri için çalışmalar arası varyansın Türkçe dil becerilerinin gelişimi açısından anlamlı olmadığı görülmektedir. Yayın türü bakımından varyanslar arasında anlamlı fark olmamasına rağmen makalelerin etki büyüklüğünün lisansüstü tezlerin etki büyüklüğünden yüksek olduğu görülmektedir. Bu durum makalelerde yayın yanlıı̆̆ı olasılığının daha yüksek olması ile açıklanabilir. Rust, Lehmann ve Farley (1990) bu duruma dikkat çekerek makale, kitap gibi basılı yayınların güçlü bir etki ya da istatistiksel anlamlılığa sahipse basılmaya uygun görüldüğünü ifade etmiş ve meta analiz çalışmalarında yayın yanlılığı açısından bunun bir problem olabileceğini belirtmişlerdir. Bu doğrultuda bu meta analiz araştırmasında veriler toplanırken lisansüstü tezlerden üretilen makalelere ulaşılması durumunda, daha fazla veri içerdiği ve yayın yanlılığı olasılığının görece düşük olduğu öngörüsüyle lisansüstü tezler meta analize dâhil edilmiştir. Böylece daha sağlıklı sonuçlar elde edilmeye çalışılmıştır.

Beceri alanı (dinleme, okuma, yazma, dil bilgisi) moderatör değişkeni incelendiğinde, beceri alanları arasındaki varyansın Türkçe dil becerilerinin gelişimi açısından anlamlı olmaması dijital öykülerin bütün dil becerilerinin gelişimi üzerinde olumlu etkiye sahip olduğunu göstermektedir. Alanyazında yer alan ana dili ve yabancı dil eğitimine yönelik birçok çalışmada dijital öyküleme uygulamalarının veya araştırmacıların hazırladığı, öğrenme aracı olarak kullanılan dijital öykülerin konuşma (Abdolmanafi-Rokni ve Qarajeh, 2014; Tatlı ve Aksoy, 2017), dinleme (Abidin, PourMohammadi, Souriyavongsa, Tiang ve Kim, 2011; Ciğerci, 2015; Demirbaş, 2019; Türe-Köse, 2019; Verdugo ve Belmonte, 2007), okuma (Adıgüzel ve Kumkale, 2018; Çiftçi, 2019; Özerbaş ve Öztürk, 2017; Şentürk-Leylek, 2018; Yılmaz, Üstündağ, Güneş ve Çalışkan, 2017), yazma (Baki, 2015, 2019; BalamanUçar, 2016; Çıralı, 2014; Dayan, 2017; Demirbaş, 2019; Duman ve Göçen, 2015; Gider, 2019; Gündüz, 2019; Uslu, 2019; Yamaç, 2015; Yılmaz vd., 2017) olmak üzere dil becerilerinin gelişiminin yanı sıra sözcük öğrenimi (Aitkuzhinova-Arslan, Gün ve Üstünel, 2016; Özer, 2016; Yardım, 2011) ve dil becerilerinin gelişimine temel oluşturan dil bilgisi öğretimi (Özkaya, 2017) üzerinde etkili olduğu tespit edilmiştir. Bu da dijital öykülerin bütün dil becerilerinin gelişimi üzerinde olumlu etkiye sahip olduğu sonucunu desteklemektedir. Beceri alanı (dinleme, okuma, yazma, dil bilgisi) bakımından varyanslar arasında anlamlı fark olmamasına rağmen yazma becerisine ait etki büyüklüğünün diğer beceri alanlarına ait etki büyüklüklerinden daha yüksek olduğu görülmektedir. Dijital öyküleme kendi içinde “öyküyü yazma", "öykü panosu oluşturma", "dijital öyküyü hazırlama” ve "dijital öyküyü paylaşma” aşamalarını barındırmaktadır. Bu bağlamda varyanslar arasında anlamlı fark olmasa da yazma becerisine ait etki büyüklüğünün diğer becerilere göre daha yüksek çıkmasının nedeni yazma aşamasının dijital öyküleme sürecinin temel basamağını oluşturmasından kaynaklanabilir. Dijital öyküleme sürecinde yazma, yazılanları düzenleme ve sonrasında yazılanları dijital hâle getirme aşamalarının önemi dikkate alındığında dijital öykünün etkili olabilmesi için ilk olarak öğrencilerin yazma becerisinin geliştirilmesi gerektiği ortaya çıkmaktadır. Alanyazında yer alan birçok araştırmada dijital öykülerin yazma sürecinde öğrencilerin düzenleme becerilerini geliştirdiği ifade edilmiştir (Baki, 2015; Dayan ve Girmen, 2018; Doğan ve Robin, 2008; Rahimi ve Yadollahi, 2017; Robin, 2008). Bu da yazma becerisinin gelişimiyle paralel olarak dijital öykülemenin etkisinin artabileceğini göstermektedir. 
Öğrenim düzeyi (ilkokul, ortaokul, lisans) moderatör değişkeni incelendiğinde, çalışmalar arası varyansın Türkçe dil becerilerinin gelişimi açısından anlamlı olduğu tespit edilmiştir. Buna göre çalışmaların farklı öğrenim düzeylerinde yapılmış olması Türkçe dil becerilerinin gelişimi değişkenine göre hesaplanan etki büyüklüğünü değiştirmektedir. Etki büyüklüklerinin ortalamaları incelendiğinde, öğrenim düzeyi bakımından lisans düzeyinde yapılan çalışmaların Türkçe dil becerilerinin gelişimi üzerindeki etkisinin daha yüksek olduğu görülmektedir. Meta analiz kapsamında lisans öğrenim düzeyini temsil eden sadece bir çalışma bulunmaktadır (Duman ve Göçen, 2015). Bu sebeple söz konusu etki büyüklüğünü lisans gruplarına genellemek doğru olamayacağından sadece mevcut durum hakkında bilgi verdiğini söylemek daha uygun olacaktır. Öğrenim düzeyi değişkeninde lisans düzeyini temsil eden söz konusu çalışma çıkarılıp analiz tekrar yapılınca çalışmalar arası varyansın anlamlı olmadığı tespit edilmiştir (Qöğrenim düzeyi= $.375 s d=1 ; p>.05$ ). Bu durum, söz konusu çalışmaya ait etki büyüklüğünün yüksek olması nedeniyle lisans öğrenim düzeyini temsil eden etki büyüklüğünün yüksek çıkması sonucunu destekler niteliktedir. Meta analize dâhil edilen çalışmaların etki büyüklükleri incelendiğinde de etki büyüklüğü en yüksek olan çalışmanın Duman ve Göçen'e (2015) ait olması bu sonucu desteklemektedir. Öğrenim düzeyi (ilkokul, ortaokul, lisans) moderatör değişkenine ait bulgular incelendiğinde bütün öğrenim düzeylerine ait etki büyüklüklerinin pozitif yönde olduğu görülmektedir. Bu da dijital öykülerin bütün öğrenim düzeylerinde etkili bir yöntem olduğu sonucunu ortaya çıkarmaktadır. Alanyazındaki birçok çalışmada, dijital öykülerin dil becerilerinin gelişiminin yanı sıra fen bilimleri (Galbreath, 2015; Hung, Hwang ve Huang, 2012; Kahraman, 2013, Nam, 2017), fen eğitimi (Büyükcengiz, 2017; Torun, 2016; Ulum, 2017), sosyal bilgiler eğitimi (Demirer, 2013), güzel sanatlar eğitimi (Ayvaz-Tunç, 2016), değerler eğitimi (Yürük, 2015), okul öncesi eğitimi (Başdaş, 2017; Gözen ve Cırık, 2017), yetişkin eğitimi (Prins, 2017) gibi farklı disiplinlerde ve öğretmenler (Doğan ve Robin, 2008; Gordon, 2011; Karakoyun, 2014), öğretmen adayları (Gakhar, 2007; Göçen, 2014; Göçen-Kabaran ve Aldan-Karademir, 2017; Shelton, Archambault ve Hale, 2017; Yavuz-Konokman, 2015) ve öğrenciler (Baki, 2015; Ciğerci, 2015; Çıralı, 2014; Çiftçi, 2019; Demirbaş, 2019; Özerbaş ve Öztürk, 2017; Özkaya, 2017; Uslu, 2019) gibi farklı gruplar üzerinde etkili olduğu tespit edilmiştir. Buna göre dijital öykülerin farklı yaş gruplarında ve farklı disiplinlerde de etkili olduğu söylenebilir.

Yapılan meta analiz çalışması doğrultusunda dijital öykülerin bireylerin Türkçe dil becerilerinin gelişiminde etkili bir yöntem olduğu sonucuna ulaşılmıştır. Bu sonuçtan hareketle ana dili eğitiminde öğrencilerin dil becerilerinin gelişimini desteklemek amacıyla dijital öykülerden faydalanılabilir. Dijital öyküler sınıf içinde bir öğrenme aracı olarak kullanılabileceği gibi dersler öğrencilere dijital öyküleme etkinlikleri yaptırılacak şekilde yapılandırılarak bir yöntem olarak da dijital öykülemeden faydalanılabilir. Dijital öyküleme sadece dil becerilerinin gelişiminde değil farklı disiplinlerde de uygulanan bir yöntemdir. Alanyazın incelendiğinde dijital öyküleme yönteminin öğrencilerin akademik başarıları, tutumları gibi değişkenler üzerindeki etkisini belirlemeye yönelik meta analiz çalışmalarına ulaşılamamıştır. Bu doğrultuda farklı disiplinlerdeki çalışmaların da dâhil edilmesiyle dijital öyküleme yönteminin veya dijital öykülerin akademik başarı, tutum ya da farklı değişkenler üzerindeki etkisini belirlemeye yönelik meta analiz çalışmaları yapılabilir.

Araştırma kapsamında yapılan moderatör değişken analizinde yayın türü bakımından varyanslar arasında anlamlı fark olmamasına rağmen makalelerin etki büyüklüğünün lisansüstü tezlerin etki büyüklügünden yüksek olduğu görülmektedir. Bu meta analiz araştırmasında veriler toplanırken lisansüstü tezlerden üretilen makalelere ulaşılması durumunda, lisansüstü tezler meta analize dâhil edilmiştir. Böylece daha sağlıklı sonuçlar elde edilmeye çalışılmıştır. Yapılacak meta analiz çalışmalarında veriler toplanırken yayın yanlılığını düşürmek amacıyla lisansüstü tezlerden üretilen makalelere ulaşılması durumunda, daha fazla veri içerdiği ve yayın yanlılığı olasılığının görece düşük olduğu öngörüsüyle lisansüstü tezler meta analize dâhil edilebilir.

Araştırma sonuçlarından hareketle dijital öykülerin bütün öğrenim düzeylerinde Türkçe dil becerilerinin gelişiminde etkili olabileceği söylenebilir. Bu bağlamda okul öncesinden başlayarak ilkokul, ortaokul, lise ve lisansüstü düzeylerde Türkçe derslerinde dijital öykülerden ve dijital öyküleme yönteminden faydalanılabilir. Bu doğrultuda dijital öyküleme yönteminin ve dijital öykülerin doğru kullanımının sağlanması ve öğretmenler arasında yaygınlaşması amacıyla hizmet içi eğitimler düzenlenebilir. Aynı şekilde lisans düzeyinde derse giren öğretim üyelerinin/görevlilerinin dijital 
öyküler ve dijital öyküleme konusunda bilgilendirilmesine yönelik eğiticilerin eğitimi projeleri üretilebilir.

Araştırmada ortaya çıkan sonuçlardan biri de dijital öykülerin bütün dil becerilerinin gelişimi üzerinde olumlu etkiye sahip olmasıdır. Bu doğrultuda dijital öyküler öğrencilerin dinleme/izleme, okuma, konuşma ve yazma becerilerinin gelişiminde birer öğrenme aracı olarak kullanabilir. Ayrıca bir yöntem olarak dijital öykülemenin kullanılmasıyla öğrencilerin kendi dijital öykülerini oluşturmaları, bütün dil becerilerini aktif olarak kullanabilmeleri bakımından etkili olacaktır. Yöntemin etkili olabilmesi için öğretmenin rehber olması ve öğrencilerin dijital öyküleme sürecindeki aşamaları doğru bir biçimde uygulayabilmeleri oldukça önemlidir. Bu bağlamda sınıf içinde dijital öyküleme uygulamalarına geçilmeden önce birkaç hafta süresince öğretmen tarafından öğrencilere dijital öyküleme yöntemini tanıtıcı, dijital öykü oluşturma aşamalarına yönelik bilgilendirici eğitimler verilmesi yöntemin sınıf içinde daha kolay uygulanmasını sağlayacaktır.

Araştırmadan elde edilen beceri alanı bakımından varyanslar arasında anlamlı fark olmamasına rağmen yazma becerisine ait etki büyüklüğünün diğer beceri alanlarına ait etki büyüklüklerinden daha yüksek olduğu sonucundan hareketle yazma becerisinin dijital öykü oluşturmada öncelikli olarak önemsenmesi gereken bir beceri olduğu söylenebilir. Dijital öyküleme sürecinin temel aşaması "öyküyü yazma" basamağıdır. Dijital öykünün etkili olabilmesinin ilk koşulu öykü metninin amacına uygun, metinsellik ölçütleri doğrultusunda hazırlanmasıdır. Bu bağlamda dijital öykü oluşturma uygulamalarına geçilmeden önce öğrencilerin yazma becerileri geliştirilmelidir. Öğrencilerin yazma becerilerini geliştirmek için sınıf içinde başta öykü olmak üzere farklı türlerde metin oluşturmalarına yönelik çok sayıda yazma çalışmaları yaptırılabilir. Öğrencilerin ilgisini arttırmak amacıyla yazma etkinlikleri yaratıcı drama, yaratıcı yazma, duyulardan hareketle yazma gibi farklı yöntem ve tekniklerle zenginleştirilebilir. Dijital öykülerin öğretmen tarafından hazırlanıp öğrenme aracı olarak kullanılması durumunda, dijital öykülerin etkili olması için öykü metinlerinin amaca uygun bir bağlam dâhilinde özenle oluşturulması, gereksiz tekrara düşmeden açık ve anlaşıı bir dil kullanılması öncelikli olarak önemsenmelidir.

\section{Kaynaklar}

Yıldız $\left(^{*}\right)$ ile işaretli çalışmalar meta analize dâhil edilmiştir.

Abidin, M. J. Z., Pour-Mohammadi, M., Souriyavongsa, T., Tiang, C. D. B. ve Kim, N. O. L. (2011). Improving listening comprehension among Malay preschool children using digital stories. International Journal of Humanities and Social Science, 1(14), 159-164.

Abdolmanafi-Rokni, S. J. ve Qarajeh, M. (2014). Digital storytelling in EFL classrooms: The effect on the oral performance. International Journal of Language and Linguistics, 2(4), 252-257.

Adıgüzel, A. ve Kumkale, Z. (2018). The effect of digital story preparation program on reading comprehension in English. Electronic Journal of Education Sciences, 7(14), 176-186.

Aitkuzhinova-Arslan, A., Gün, S. ve Üstünel, E. (2016). Teaching vocabulary to Turkish young learners in semantically related and semantically unrelated sets by using digital storytelling. Dil ve Dilbilimi Çalışmaları Dergisi, 12(1), 42-54.

Akgöz, S., Ercan, İ. ve Kan, İ. (2004). Derleme meta-analizi. Uludağ Üniversitesi Tıp Fakültesi Dergisi, 30(2), 107-112.

Aldağ, H. (2005). Öğrenme ve öğretmede A. Paivio'nun ikili kodlama kuramı. Ç.Ü. Sosyal Bilimler Enstitüsü Dergisi, 14(2), 29-48.

Aldağ, H. ve Sezgin, M. E. (2002). Multimedya uygulamalarında ikili kodlama kuramı. M.Ü. Atatürk Eğitim Fakültesi Eğitim Bilimleri Dergisi, 15, 29-44.

Ayvaz-Tunç, Ö. (2016). Dijital teknolojiler bağlamında dijital öyküleme yaklaşımının güzel sanatlar eğitimine entegrasyonu (Yayımlanmamış doktora tezi). Ondokuz Mayıs Üniversitesi, Eğitim Bilimleri Enstitüsü, Samsun.

*Baki, Y. (2015). Dijital öykülerin altıncı sınıf öğrencilerinin yazma sürecine etkisi (Yayımlanmamış doktora tezi). Atatürk Üniversitesi, Eğitim Bilimleri Enstitüsü, Erzurum.

Bakioğlu, A. ve Göktaş, E. (2018). Bir eğitim politikası belirleme yöntemi: Meta analiz. Medeniyet Eğitim 
Araştırmaları Dergisi, 1(2), 35-54.

Balaman-Uçar, S. (2016). The impact of digital storytelling on English as a foreign language learners' writing skills (Yayımlanmamış doktora tezi). Hacettepe Üniversitesi, Eğitim Bilimleri Enstitüsü, Ankara.

Başdaş, F. (2017). Drama temelli dijital hikâye anlatıcılığı programının 6 yaş çocuklarının bazı sosyal becerilerinin gelişimine etkisi (Yayımlanmamış yüksek lisans tezi). Adnan Menderes Üniversitesi, Sosyal Bilimler Enstitüsü, Aydın.

Borenstein, M., Hedges, L. V., Higgins, J. P. T. ve Rothstein, H. R. (2009). Introduction to meta-analysis. UK: John Wiley \& Sons.

Büyükcengiz, M. (2017). Dijital öyküleme metodunun ortaokul öğrencilerinin fen bilimleri dersi akademik başarı, bilimsel süreç becerileri ve derse yönelik tutumlarına etkisi (Yayımlanmamış yüksek lisans tezi). Akdeniz Üniversitesi, Eğitim Bilimleri Enstitüsü, Antalya.

Büyüköztürk, Ş., Kılıç-Çakmak, E., Akgün, Ö. E., Karadeniz, Ş., ve Demirel, F. (2018). Bilimsel araştırma yöntemleri (24. Baskı). Ankara: Pegem Akademi.

Card, N. A. (2011). Applied meta-analysis for social science research: Methodology in the social sciences. New York: Guilford.

*Ciğerci, F. M. (2015). ilkokul dördüncü sınıf Türkçe dersinde dinleme becerilerinin geliştirilmesinde dijital hikâyelerin kullanılması (Yayımlanmamış doktora tezi). Anadolu Üniversitesi, Eğitim Bilimleri Enstitüsü, Eskişehir.

Cohen, J. (1988). Statistical power analysis for the behavioral sciences (2. Baskı). New Jersey: Lawrence Erlbaum Associates.

Cumming, G. (2012). Understanding the new statistics (effect sizes, confidence, intervals and metaanalysis). New York: Routledge.

*Çıralı, H. (2014). Dijital hikâye anlatımının görsel bellek ve yazma becerisi üzerine etkisi (Yayımlanmamış yüksek lisans tezi). Hacettepe Üniversitesi, Eğitim Bilimleri Enstitüsü, Ankara.

*Çiftçi, M. (2019). Dijital hikâyelerin ilkokul ikinci sınıf öğrencilerinin okuma becerileri üzerindeki etkisi (Yayımlanmamış yüksek lisans tezi). Aksaray Üniversitesi, Sosyal Bilimler Enstitüsü, Aksaray.

Dağıstan, G. (2015). Ingilizce dersinde kullanılan bellek destekleyici stratejilerden öyküleme yönteminin kelime bilgisine etkisi (Yayımlanmamış yüksek lisans tezi). Kırşehir Ahi Evran Üniversitesi, Sosyal Bilimler Enstitüsü, Kırşehir.

Dayan, G. (2017). ilkokul öğrencilerinin Türkçe dersinde dijital öyküleme çalışmaları (Yayımlanmamış yüksek lisans tezi). Eskişehir Osmangazi Üniversitesi, Eğitim Bilimleri Enstitüsü, Eskişehir.

Dayan, G. ve Girmen, P. (2018). Türkçe eğitimi yazma sürecinde: Dijital öyküleme. Eğitimde Nitel Araştırmalar Dergisi, 6(3), 207-228.

Demir, S. (2012). The effect of storyline method on students' achievements in 5th grade of science and technology courses. Procedia-Social and Behavioral Sciences, 46, 5026-5029.

*Demirbaş, i. (2019). Dijital öykülerin ilkokul öğrencilerinin dinlediğini anlama ve yaratıcı yazma becerilerine etkisi (Yayımlanmamış Yüksek Lisans Tezi). Kırşehir Ahi Evran Üniversitesi, Sosyal Bilimler Enstitüsü, Kırşehir.

Demirer, V. (2013). ilköğretimde e-öyküleme kullanımı ve etkileri (Yayımlanmamış doktora tezi). Necmettin Erbakan Üniversitesi, Eğitim Bilimleri Enstitüsü, Konya.

Dinçer, S. (2014). Eğitim bilimlerinde uygulamalı meta-analiz. Ankara: Pegem Akademi.

Doğan, B. ve Robin, B. R. (2008). Implementation of digital storytelling in the classroom by teachers trained in a digital storytelling workshop. Proceedings of Society for Information Technology \&Teacher Education International Conference. 19.06.2020 tarihinde http://www.editlib.org/p/27287 adresinden erişildi.

*Duman, B. ve Göçen, G. (2015). The effect of the digital storytelling method on pre-service teachers' creative writing skills. Anthropologist, 20(1-2), 215-222.

Duran, E. ve Ertan-Özen, N. (2017). Dijital öyküler ve Türkçe eğitiminde kullanımı. Avrasya Dil Eğitimi ve Araştırmaları Dergisi, 1(1), 76-105.

Figa, E. (2004). The virtualization of stories and storytelling. Storytelling Magazine, 16 (2), 34 - 36. 
Gakhar, S. (2007). The influence of a digital storytelling experience on pre-service teacher education students' attitudes and intentions. University of lowa State, USA. 19.06.2020 tarihinde http://lib.dr.iastate.edu/cgi/viewcontent.cgi?article=16050\&context=rtd adresinden erişildi.

Galbreath, M. A. (2015). Voices of place: The affordances and barriers for teaching underrepresented students who employ digital stories to articulate their interpretations of place meaning. University of Idaho. 19.06 .2020 tarihinde https://search.proquest.com/docview/1752638579?pq-origsite=gscholar adresinden erişildi.

*Gider, B. (2019). Bireysel ve işbirlikli dijital öyküleme uygulamalarının üstün zekâlı öğrencilerin yazma performansına ve dil gelişimine etkisi (Yayımlanmamış yüksek lisans tezi). Kırklareli Üniversitesi, Sağlık Bilimleri Enstitüsü, Kırklareli.

Gordon, C. (2011). Digital storytelling in the classroom: Three case studies (Unpublished doctoral dissertation). University of Arizona State, USA. 19.06.2020 tarihinde https://repository.asu.edu/attachments/93320/content//tmp/packagefD9mbW/Gordon_asu _0010E_11221.pdf adresinden erişildi.

Göçen, $\bar{G}$. (2014). Dijital öyküleme yönteminin öğrencilerin akademik başarı ile öğrenme ve ders çalışma stratejilerine etkisi (Yayımlanmamış yüksek lisans tezi). Muğla Sıtkı Koçman Üniversitesi, Eğitim Bilimleri Enstitüsü, Muğla.

Göçen-Kabaran, G. ve Aldan-Karademir, Ç. (2017). Digital storytelling experiences of pre-service teachers: An action research. Online Submission, 12(6), 369-386.

Gözen, G. ve Cırık, i. (2017). Dijital öykülemenin okul öncesi çocukların sosyal-duygusal davranışlarına etkisi. ilköğretim Online, 16(4). 1882-1896.

Gündüz, N. (2019). Dijital öykü yazarlığının çeşitli değişkenlere göre incelenmesi (Yayımlanmamış Yüksek Lisans Tezi). Dokuz Eylül Üniversitesi, Eğitim Bilimleri Enstitüsü, İzmir.

Güneş, F. (2013). Türkçede metin öğretimi yerine metinle öğrenme. Adıyaman Üniversitesi Sosyal Bilimler Enstitüsü Dergisi, 6(11), 603-637.

Gürol, A. ve Kerimgil, S. (2012). Primary school education pre-service teachers' views about the application of storyline method in social studies teaching. International Online Journal of Educational Sciences, 4(2), 325-334.

Huedo-Medina, T. B., Sanchez-Meca, J., Marin-Martinez, F. ve Botella, J. (2006). Assessing heterogeneity in meta-anlaysis: Q statistic or $\mathrm{I}^{2}$ index? Psychological Methods, 11(2), 193-206.

Hung, C. M., Hwang, G. J. ve Huang, I. (2012). A project-based digital storytelling approach for improving students' learning motivation, problem-solving competence and learning achievement. Journal of Educational Technology \& Society, 15(4), 368-379.

Kahraman, Ö. (2013). Dijital hikâyecilik metoduyla hazırlanan öğretim materyallerinin öğrenme döngüsü giriş aşamasında kullanılmasının fizik dersi başarısı ve motivasyonu düzeyine etkisi (Yayımlanmamış doktora tezi). Balıkesir Üniversitesi, Fen Bilimleri Enstitüsü, Balıkesir.

Karakoyun, F. (2014). Çevrimiçi ortamda oluşturulan dijital öyküleme etkinliklerine ilişkin öğretmen adayları ve ilköğretim öğrencilerinin görüşlerinin incelenmesi (Yayımlanmamış doktora tezi). Anadolu Üniversitesi, Eğitim Bilimleri Enstitüsü, Eskişehir.

Kurudayıoğlu, M. ve Bal, M. (2014). Ana dili eğitiminde dijital hikâye anlatımlarının kullanımı. Sakarya Üniversitesi Eğitim Fakültesi Dergisi, 28, 74-95.

Meadows, D. (2003). Digital Storytelling: Research-based practice in new media. Visual Communication, 2(2), 189-193.

MEB (2019). Türkçe Dersi (ilkokul ve Ortaokul 1, 2, 3, 4, 5, 6, 7 ve 8. Sınıflar) Öğretim Programı. Ankara: MEB.

Miller, C. H. (2004). Digital storytelling: A creator's guide to interactive entertainment.

Taylor \& Francis. $19.06 .2020 \quad$ tarihinde https://books.google.com.tr/books?id=kWFosl5j3fIC\&printsec=frontcover\&hl=tr\&source=gbs _ge_summary_r\&cad=0\#v=onepage\&q\&f=false adresinden erişildi.

Mitchell, P. (2016). The impact of the storyline method on the foreign language classroom: an action research case study with military linguist cadets (Doctoral dissertation). University of Derby,UK. 
Nam, C. W. (2017). The effects of digital storytelling on student achievement, social presence, and attitude in online collaborative learning environments. Interactive Learning Environments, 25(3), 412-427.

Ohler, J. (2006). The world of digital storytelling. Educational Leadership, 44-47.

Özer, M. (2016). Exploring the role of digital storytelling in vocabulary learning and retention: A case study at Harran University (Yayımlanmamış yüksek lisans tezi). Harran Üniversitesi, Eğitim Bilimleri Enstitüsü, Şanlıurfa.

*Özerbaş, M. A. ve Öztürk, Y. (2017). Türkçe dersinde dijital hikâye kullanımının akademik başarı, motivasyon ve kalıcılık üzerinde etkisi. TÜBAV Bilim Dergisi, 10(2), 102-110.

* Özkaya, P. G. (2017). Bilgi teknolojilerine dayalı hikâye anlatımıyla öbek-anlam ilişkisinin kavranması (Yayımlanmamış doktora tezi). Muğla Sıtkı Koçman Üniversitesi, Eğitim Bilimleri Enstitüsü, Muğla.

Pigott, T. (2012). Advances in meta-analysis. Chicago: Springer.

Prins, E. (2017). Digital storytelling in adult education and family literacy: A case study from rural Ireland. Learning, Media \& Technology, 42(3), 308-323.

Rahimi, M., ve Yadollahi, S. (2017). Effects of offline vs. online digital storytelling on the development of EFL learners' literacy skills. Cogent Education, 4(1), 1285531.

Robin, B. R. (2008). Digital storytelling: A powerful technology tool for the 21st century classroom. Theory Into Practice, 47(3), 220-228.

Rothstein, H. R., Sutton, A. J. ve Borenstein, M. (2005). Publication bias in meta-analysis: Prevention, assessment and adjustments. England: John Wiley \& Sons.

Rust, R. T., Lehmann, D. R., ve Farley, J. U. (1990). Estimating publication bias in meta-analysis. Journal of Marketing Research, 27(2), 220-226.

Shelton, C. C., Archambault, L. M. ve Hale, A. E. (2017). Bringing digital storytelling to the elementary classroom: Video production for preservice teachers. Journal of Digital Learning in Teacher Education, 33(2), 58-68.

Sutton, A. J. (2009). Publication bias. H. Cooper, L. V. Hedges, ve J. C. Valentine (Ed.), The handbook of research synthesis and meta-analysis (2nd ed.) içinde (s.435-452). New York: Russell Sage Foundation.

Şentürk-Leylek, B. (2018). ilkokul üçüncü sınıf öğrencilerinin okuma becerilerinin gelişiminde ve okumaya yönelik tutumlarında dijital hikayelerin etkisi (Yayımlanmamış doktora tezi). Uludağ Üniversitesi, Eğitim Bilimleri Enstitüsü, Bursa.

Takacs, Z. K., Swart, E. K., ve Bus, A. G. (2015). Benefits and pitfalls of multimedia and interactive features in technology-enhanced storybooks: A meta-analysis. Review of educational research, 85(4), 698-739.

Tatlı, Z. ve Aksoy, D. A. (2017). Yabancı dil konuşma eğitiminde dijital öykü kullanımı. Marmara Üniversitesi Atatürk Eğitim Fakültesi Eğitim Bilimleri Dergisi, 45(45), 137-152.

Tatum, M. E. (2009). Digital storytelling as a cultural-historical activity: Effects on information text comprehension (Open access dissertations). University of Miami, USA. 19.06.2020 tarihinde http://scholarlyrepository.miami.edu/cgi/viewcontent.cgi?article=1221\&context=oa_dissertati ons adresinden erişildi.

Tepetaş, G. Ş. ve Haktanır, G. (2013). 6 yaş çocuklarının temel kavram bilgi düzeylerini desteklemeye yönelik öyküleştirme yöntemine dayalı bir eğitim uygulaması. Eğitim ve Bilim, 38(169), 62-79.

Torun, B. (2016). Ortaokul 6. sınıf hücre konusunda dijital öykü kullanımının öğrenci başarısı, tutumu ve bilimsel süreç becerileri üzerine etkisi (Yayımlanmamış yüksek lisans tezi). Kastamonu Üniversitesi, Fen Bilimleri Enstitüsü, Kastamonu.

Turgut, G. ve Kışla, T. (2015). Bilgisayar destekli hikâye anlatımı yöntemi: Alanyazın araştırması. Turkish Online Journal of Qualitative Inquiry, 6(2), 97-121.

Türe-Köse, H. B. (2019). Okul öncesi dönem çocuklarında dijital hikâye anlatımının dinleme becerilerine etkisi (Yayımlanmamış yüksek lisans tezi). Dumlupınar Üniversitesi, Eğitim Bilimleri Enstitüsü, Kütahya.

Ulum, E. (2017). Yedinci sınıf öğrencilerinin fen bilimleri konularında dijital öykü hazırlama deneyimleri 
(Yayımlanmamış yüksek lisans tezi). Mersin Üniversitesi, Eğitim Bilimleri Enstitüsü, Mersin.

*Uslu, A. (2019). Issbirlikli dijital hikâye anlatımının ilkokul 4. sınıf öğrencilerinin yaratıcı yazma ve sosyal duygusal öğrenme becerilerine etkisi (Yayımlanmamış yüksek lisans tezi). Manisa Celal Bayar Üniversitesi, Sosyal Bilimler Enstitüsü, Manisa.

Verdugo, D.R. ve Belmonte, I.A. (2007). Using digital stories to improve listening comprehension with Spanish young learners of English. Language Learning \& Technology. 11(1), 87-101.

Yamaç, A. (2015). ilkokul üçüncü sınıf öğrencilerinin yazma becerilerinin gelişiminde dijital hikâyelerin etkisi (Yayımlanmamış doktora tezi). Gazi Üniversitesi, Eğitim Bilimleri Enstitüsü, Ankara.

Yardım, S. (2011). The effect of computer assisted and teacher-led storytelling on vocabulary learning of 5th grade students (Yayımlanmamış yüksek lisans tezi). Gazi Üniversitesi, Eğitim Bilimleri Enstitüsü, Ankara.

Yavuz-Konokman, G. (2015). Araştırma temelli öğrenme yaklaşımına dayalı dijital öykü oluşturmanın öğretmen adaylarının direnç davranışlarına ve öğrenme yaklaşımlarına etkisi (Yayımlanmamış doktora tezi). Mersin Üniversitesi, Eğitim Bilimleri Enstitüsü, Mersin.

Yılmaz, E. ve Taflan, S. (2010). İlköğretim 6. sınıf öğrencilerinin anlama düzeyinin artırılmasında

"öyküleme tekniği” nin kullanılması. G. L. Uzun ve B. Ü. Bozkurt (Ed.), Türkçe öğretiminde güncel tartışmalar içinde (s.262-272). Ankara: Tömer.

*Yılmaz, Y., Üstündağ, M. T., Güneş, E., ve Çalışkan, G. (2017). Dijital hikâyeleme yöntemi ile etkili Türkçe öğretimi. Eğitim Teknolojisi Kuram ve Uygulama, 7(2), 254-275.

Yürük, S. E. (2015). Dijital öykülemeye dayalı değerler eğitiminin öğrencilerin değer kazanımı ve tutumlarına etkisi (Yayımlanmamış yüksek lisans tezi). Fırat Üniversitesi, Eğitim Bilimleri Enstitüsü, Elazığ.

\section{Introduction}

\section{Extended Abstract}

The purpose of the current study is to determine the effect of digital stories on the development of the Turkish language skills of students from different grade levels in Turkey. To this end, a meta-analysis of the studies investigating the effect of the digital stories on the development of the Turkish language skills was conducted. In the current study, moderator variable effect of the variables of grade level, type of publication and skill area on the effect sizes calculated according to the effect of digital stories on the development of the Turkish language skills was also examined.

\section{Method}

In the current study, it was aimed to determine the general effect size of digital stories on the development of the Turkish language skills through the meta-analysis method. The data of the current study were collected in June 2020. In order to reach the studies to be used in the current study, the key words "dijital öyküleme, dijital öykü, dijital öyküleyicilik, dijital hikâye, dijital hikâye anlatımı, eöyküleme, bilgi teknolojilerine dayalı hikâye anlatımı, dil becerileri, Türkçe eğitimi" and their English translations were used to search in Google Scholar, Higher Education Council National Thesis Centre, ULAKBIM TR Dizin, ProQuest Citations, ISI (SCl expanded, SSCI, ESCI), Australian Education, ERIC and EBSCOhost data bases. In order to determine which of the reached studies would be included in the current meta-analysis study, some criteria were determined. These criteria are; (1) The study should be a thesis study completed in the period 2014-2018 or an article published in reviewed journals in the same period, (2) The study should be focused on the determination of digital stories on the development of the Turkish language skills, (3) The study should have an experimental and control group; that is, it should be quasi experimental, (4) The experimental group students should be taught with digital stories and the control group students should be taught with traditional teaching methods, (5) Data collection tools aiming to determine the effect of the digital stories on the development of the Turkish language skills should be used, (6) The number of the participants making up the control and experimental groups should be given, (7) Arithmetic means, standard deviations, $p$ values or the statistics required to calculate the effect size should be reported. 
On the basis of these criteria, a total of 11 studies were included in the current meta-analysis study. The total sample size of the studies included in the meta-analysis is 566 students; 286 in the control groups and 280 in the experimental groups. The studies included in the meta-analysis are heterogonous. In addition to result of the funnel scatter plot related to publication bias, absence of the publication bias was confirmed with Orwin's Safe N Analysis, Duval and Tweedie's Trip and Fill and Egger's regression analysis. Effect sizes were calculated according to the random effects model. In the calculations of the effect sizes, Cohen's $d$ coefficient was used. In the current study, moderator variable effect of the variables of grade level, type of publication and skill area on the effect sizes calculated according to the effect of the digital storytelling method on the development of the Turkish language skills was also examined. In the determination of the moderator variable effect, $Q$ test and $p$ significance coefficient were used.

\section{Result and Discussion}

In the current study, digital stories was found to have a high level of effect on the development of the Turkish language skills. When the results of the moderator variable analysis were examined, it was found that for the type of publication and skill area moderator variables, the between-studies variance is not significant in terms of the development of the Turkish language skills while it was found to be significant in favour of the undergraduate level variable for the grade level moderator variable. However, as there is only one study representing the undergraduate level, it would not be correct to generalize this effect size to undergraduate groups, it was excluded from the analysis considering that it would only provide information about the current state and the analysis was repeated. As a result of the analysis, it was seen that there is no significant difference between the variances in terms of the grade level moderator variable. In light of the findings of the current study, it can be argued that digital stories has a positive effect on the development of all the Turkish language skills in all the Turkish language skill areas and different grade levels. Thus, it can be suggested that digital stories can be used supporting the development of language skills of students in mother tongue education. 